DOI: 10.34015/2523-4552.2019.2.08

УдК 343.8

\author{
Z. M. Khasia, \\ PhD student of the Tbilisi State University \\ of Georgia, Prison System Advisor of the \\ International Committee of the Red Cross \\ e-mail:maiakhasia@gmail.com
}

\title{
PERSONS WITH DISABILITIES AND THEIR MULTIPLE NEEDS IN PENITENTIARY ESTABLISHMENTS
}

The present article discusses the special categories with multiple needs that any penitentiary establishment faces in its practice periodically. The purpose of this article is to briefly discuss and explain the importance of granting the PWDs with a status, appropriate to their multiple needs; as well as the importance of addressing such comprehensive needs in the context of the treatment of persons with disabilities and, on its basis, establishing conditions for serving a sentence on an equal basis with other convicted persons and in line with honour and human dignity.

Keywords: person with disabilities; penitentiary system; reasonable accommodation; adapted environment; penitentiary establishment; barrier; treatment; status determination.

В статье рассмотрены особенности отбывания наказания в виде лишения свободы специальными категориями заключенных инвалидов с особыми потребностями. Цель статьи - обсудить и объяснить важность предоставления некоторым заключенным инвалидам статуса, отвечающего их потребностям, а также необходимость удовлетворения таких потребностей в контексте работы персонала учреждений исполнения наказаний. Для таких лиц необходимо создать определенные условия для отбывания наказания наравне с другими осужденными, соблюдая права человека и гражданина.

Ключевые слова: лица с ограниченными возможностями; надлежащие условия проживания; адаптированная среда; учреждение исполнения наказаний; барьеры; лечение; определение статуса; наказание.

Introduction. Clearly, prisoners with disabilities are vulnerable persons, due to their condition, as their physical and mental disabilities predetermine their particular vulnerability in such a dangerous and closed environment as a prison [1, p. 55].

In addition to the circumstance that persons with disabilities (hereinafter - PWDs) in penitentiary establishments belong to a special category in itself, there are persons among them who also belong to other special categories, which determines their multiple needs. However, the legislations regulating penitentiary systems of many countries, and in particular the legislations of the post-Soviet countries $[2 ; 3 ; 4 ; 5]$, does not recognize the status of persons with multiple needs. 
In the category of prisoners with disabilities with multiple needs, we should consider PWDs who at the same time belong to national, religious, ethnic and racial minorities; foreign prisoners; women; juveniles; lesbian, gay, bisexual and transgender prisoners with disabilities. Prisoners with disabilities belonging to this category represent a particularly high-risk group, due to their multiple needs. Therefore, their needs and ways of meeting these needs should be assessed and planned in a comprehensive manner in conjunction with the needs related to their disability.

The purpose of this article is to briefly discuss and explain the importance of granting the PWDs with a status, appropriate to their multiple needs; as well as the importance of addressing such comprehensive needs in the context of the treatment of persons with disabilities and, on its basis, establishing conditions for serving a sentence on an equal basis with other convicted persons and in line with honour and human dignity.

The present article discusses the special categories with multiple needs that any penitentiary establishment faces in its practice periodically.

Results and discussion.

Foreign Prisoners, Ethnic and

\section{Racial Minorities.}

The language barrier should be discussed as the very first one among the factors causing additional needs specific to foreign prisoners. The language barrier does not allow them to have full contact with the administration or other prisoners. Therefore, they may be unable to provide the administration with information about their disabilities and claim the service relevant to their condition.
All categories of foreign prisoners have special needs, which include challenges, such as remoteness from the family, «foreign national prisoners who were not resident in the country of imprisonment are usually cut off from their families and communities, and therefore lack the contact and support that is vital to reduce the harmful effects of imprisonment and assist with social reintegration» [6, p. 82], which is particularly critical with regard to persons with disabilities, who are largely dependent on the support of these people before entering the prison. As for ethnic and racial minorities, the language barrier may not be so severe, as they may know or understand the state language due to the long stay in the given country. However, the additional needs, that foreign prisoners face, extend to ethnic and racial minorities as well, and are related to their cultural characteristics, tradition, religion and nationality, which often cannot be provided by penitentiary systems.

The article discusses a list of problems, which this category of persons with disabilities may encounter in prison, namely:

a. Submitting written request to receive appropriate services, meet with the prison director or doctor and other personnel, which foreign prisoners or national and ethnic minorities may not have access to without support, due to lack of knowledge of the state language or lack of appropriate education. National regulations or international standards related to a penitentiary system allow foreign prisoners to contact their diplomatic representatives [7], however, often they may not be aware of this possibility, because they do not have access to these regulations or have not been explained about this right 
due to the lack of knowledge of the language.

b. Access to a doctor or psychologist, when they depend on an interpreter, whose services are often unavailable. If the administration or the prisoners themselves turn to other prisoners for help (if available), the confidentiality, required when providing medical and psychological assistance, is violated.

c. Use of disciplinary measures «there may not be copies of prison rules and regulations in a language that they understand, they may not be provided adequate interpretation during disciplinary hearings» [6, p. 61]. Thus, a prisoner with disabilities of such a group may not even know that the act s/he committed was a disciplinary violation. Also, $\mathrm{s} /$ he is not given the opportunity to defend himself and present arguments in his/her favour during the disciplinary hearing.

d. A discriminatory approach to persons with disabilities of this category can be manifested in a variety of ways. One of them is placement: isolation from other prisoners, when they are placed separately, in isolation due to their language barrier and/or religious affiliation, and when the prison administration explains this as a security measure and does not take into consideration that they are placed in a locked environment without basic daily communication.

Discriminatory approaches may also be linked to the lack of consideration of the cultural and religious needs of foreign prisoners during the examination, placement and application of disciplinary sanctions [1, p. 14].

The discriminatory approach related to placement can be expressed by the quality of accommodation, the unofficial selection of certain ethnic groups and their placement in cells with less favourable living conditions. Often ethnic minorities or foreigners are placed in one cell as they can communicate with one another, however, the prison administration does not consider the degree of their disabilities and the suitability of the cell environment, the prisoner's requirement, living conditions, etc.

e. Programs and preparation for release. Prisoners with disabilities of the above category may also not be offered educational, employment or other rehabilitation programs, because they are persons with disabilities, and in addition they are foreigners, national or ethnic minorities, and the administration either does not have corresponding programs, or offers work or programs, which they are forced to take part in due to the absence of other alternatives. «Access to education, health care and prisoner programmes may be affected by ethnicity, race and descent, with a detrimental effect on the social reintegration needs of overrepresented groups, increasing the risks of reoffending after release» $[6$, p. 60]. Therefore, prisoners with disabilities belonging to foreign or national or ethnic minorities may be at risk of not being adequately prepared for release due to the lack of access to these programs.

Lesbian, Gay, Bisexual, and Transgender (LGBT) Prisoners.

LGBT prisoners belong to a highrisk group based on their status in many countries, including the post-Soviet countries. As stereotypes are often stronger in prisons than in the outside world, LGBT prisoners remain a particularly vulnerable group in many aspects [1, p. 31] and, above all, have the 
highest protection needs. The risk is further increased by the disability. Thus, the main objective in regards to this category of prisoners is both to meet their disability needs and protect them from violence, which is usually expected from other prisoners and, in some cases, from prison personnel [8]. For example, a research [9] conducted in the US found that «nearly a fifth (18.5 percent) of inmates who identified as homosexual and 9.8 percent who identified as bisexual or «other orientation» reported being sexually victimized, compared with 2.7 percent of heterosexual inmates».

Violence against LGBT people does not only consist of sexual relationships. In a number of post-Soviet countries where so-called "criminal subculture» represents the part of the prison management, violence also includes forced obedience, when the prisoners of this category are forced to serve other prisoners and to perform the most degrading work, and if this category of prisoners is unable to perform the assigned work, the risk is even higher. In most cases, this type of violence can only be carried out with the assistance or the silent consent of the staff, for example, prison staff may have contributed to sexual violence in exchange for bribes. There are cases when prison staff beat the LGBT prisoners or placed them in cells known with abusers [6, p. 114].

One of the major problems is stigmatization. In various papers, we find examples where other prisoners or prison staff may declare this category of persons with disabilities as female. In prisons of some countries, special labels or signs on a prison file, clothing, a dining table, a cell, or a badge may be used, or they may be permanently placed in a separate accommodation and eat on a separate table. The placement of
LGBT prisoners is one of the key factors of them becoming vulnerable [1, p. 31]. In the prison systems, it is often the case that LGBT prisoners are accommodated in isolation and worse conditions. In post-Soviet countries, prison administrations face a problem of placing the transgender prisoners, which are placed in prisons based on their sex at birth. This paves the way for sexual abuse against them.

One of the problems related to LGBT prisoners is the complaints procedures, complaints on sexual assault and rape in many prison systems, especially if it is related to violence by prison staff. As a rule, such complaints are not considered or the response of the administration is minimal. This approach is especially intensified when LGBT prisoners make such a statement that even when «complaints are acted upon, ... the stigma of having been raped remains with the prisoner and the information spreads rapidly in the prison system. The victim is therefore at risk of further victimization, unless he or she is provided with adequate and constant protection» [6, p. 107].

During the process of preparation for release, LGBT prisoners with disabilities have a particular need while participating in preparation for release programs, the first being that other prisoners do not want to participate in the program with them, the second being their disability. Thus, they develop feeling that they have no further support after release.

\section{Older Prisoners.}

Older prisoners represent a vulnerable group due to their own age, as they require special care, accommodation, medical services and programs appropriate to their age, both in a free society and in the penitentiary 
system. Given the restrictions at closed institutions, the vulnerability of older prisoners is even higher and their needs are even greater.

Studies identify the following three main categories of older prisoners [6, p. 126]:

a. The first group consists of those who were sentenced to long prison terms while young and have grown old in prison. They spend long period in prison, in isolation from the community and their families, and lose community links.

b. The second group is made up of habitual offenders, who have been in and out of prison throughout their lives. They adjust reasonably well to prison life, though such PWDs may often have chronic health problems, including particularly, a history of substance abuse.

c. The third group consists of those who have been convicted of a crime in later life. Their crimes are usually serious. This group experiences the most severe adjustment problems in prison due to their age and disability.

One of the major problems that older prisoners face is reasonable accommodation. Given their age and disability, we shall presume that they have difficulty climbing stairs, independently accessing sanitary facilities, inappropriate heat or cold, various architectural structures [1, p. 49]. This may lead to the situation when fellow prisoners request his/her transfer to another cell. «In some systems, such as the United States, older prisoners are sometimes placed in separate, protected units, where the layout corresponds to their needs and where they can receive specialist care» [6, p. 127]. Arguments have been offered in favour and against such allocation options.

In particular, argument in favour of special units consider protecting older prisoners from victimization and violence of other young, healthy prisoners. Such isolation may serve as a basis for the prison administration to develop special programs for older prisoners, using specialist staff and resources; another factor could be contributing to positive mental health.

The idea of placing older prisoners with the general population is also mainstreaming. In particular, this provides an opportunity for older prisoners to communicate with other prisoners and fill up the emptiness caused by remoteness or separation from their families. In deciding the allocation of older prisoners with disabilities in the general prison population the elementary risk assessment should be carried out.

Participation of older prisoners with disabilities in rehabilitation programs is one of the most difficult challenges: in some cases, programs do not meet their age appropriate needs, since most of prison programs are designed to cater for the needs of younger prisoners, or the programs do not take into consideration the needs related to disability.

Older prisoners with disabilities have very specific requirements in terms of their preparation for release, with differences in their needs, age, disability, duration of the sentence, and other specific characteristics. The needs will vary according to their social, economic and health conditions. Therefore, individualized pre-release programs are essential for older prisoners with disabilities to return to the society.

\section{Women Prisoners with Disabilities.}

The number of female prisoners is relatively low compared to male prisoners, with studies showing that 
depending on countries and prisons the proportion of female prisoners varies from 2 to 10 per cent [10, p. 143]. It is clear that this figure should be assessed positively, however, if we look at the same studies, prisons are not built for women, but tend to be managed from a male perspective. This applies to both architecture and security and other details. Usually, this means that prisons are designed for the needs of the majority male population and adapted (or sometimes not) to the needs of women $[10, \quad$ p. 146].This approach indicates that women are often placed in establishments where their needs are either not addressed at all or, if it is, to the extent that do not comply with their real requirements.

The particular importance of managing the process of serving a sentence by women prisoners is confirmed by the fact that the United Nations and its member States have recognized that the existing standard minimum rules for the treatment of prisoners did not cover all the requirements faced by female prisoners and developed the Rules [11, Rule 6], which regulate the standards of treatment of women prisoners in all areas of serving a sentence. Women prisoners have a wide range of special needs.

One of the most difficult challenges for many women prisoners is that of accommodation. Since some prison systems have a small number of prisons used exclusively for women prisoners (e.g., Armenia, Azerbaijan, Georgia and countries in Central Asia), in these circumstances many imprisoned women are held in accommodation which is far away from their families. On one hand, this violates their right, granted through the law and international standards, to be allocated to the prisons close to their home, and on the other hand, women, including women with disabilities are particularly in need of family assistance and support, and being located far away from their homes does not allow this. Also, one of the most important issues for women prisoners, especially women with disabilities, is to undergo a proper medical examination to identify their health needs upon admission to the establishment; consultations on women's healthcare matters; access to healthcare services relevant to their health condition, etc.

There are various aspects that should be considered as a factor determining the vulnerability of women with disabilities, such as: domestic violence; serious alcohol and drug abuse; possible sexual violence and illtreatment in places of deprivation of liberty where male staff is employed; separation with the family when women are theca retakes of their children and family; specific medical, physiological needs. According to a study [12, p. 17] carried out in the United Kingdom, 80 per cent of women prisoners have a diagnosable mental illness; 66 per cent are women with alcohol abuse or consume a dangerous amount of alcohol; 50 per cent are victims of domestic violence and 33 per cent- victims of sexual violence; a third of women lost their families and property after entering the prison system; and 37 per cent admit that they had attempted suicide.

If women with disabilities are arrested, they may develop general fears, which may exacerbate their disabilities. Thus, the Bangkok Rules encourages Member States to adopt legislation to establish alternatives to imprisonment, however, if prison 
sentences are applied, the administration of the establishment should have an appropriate plan to create adequate conditions for serving a sentence for women with disabilities, as well as to have properly trained staff. «Capacity-building for staff employed in women's prisons shall enable them to address the special social reintegration requirements of women prisoners and manage safe and rehabilitative facilities» [11, Rule 29].

\section{Juvenile Prisoners with}

Disabilities.

All the rights related to persons with disabilities shall apply to any person deprived of their liberty, however, the primary attention should be given to juvenile prisoners with disabilities. When working with this category, along with disabilities, the prison administration must take into account the additional age-related circumstances. This category shall not be classified as a high-risk group and placed in a high-risk establishment or the juvenile unit of such an establishment until qualified personnel working with juveniles assesses the risk at a highly professional level. A long-term sentence shall not be applied to a juvenile offender. He should have access to a wide range of early conditional release possibilities [13].

International law gives priority to non-institutional approach, which means that «it is not prohibited to use prison sentences against children, but it is beyond a doubt that it should be used only as the last resort» [14, p. 83].Custodial sentences should be used with extra caution towards juveniles, as they are generally completely dependent on family members or other persons who are responsible for their care. They have practically no experience of living independently and thus their degree of vulnerability is extremely high. Even in case of their detention, «they must be provided with accommodation in institutions equipped with personnel and age-appropriate facilities» $[15$, p. 172].

Any measures used against juveniles should serve the crime prevention. In regards to juveniles and, in particular, the vulnerable groups (PWDs) priority should be given to the use of non-custodial sentences, diversion and mediation, in order not to inflict more physical and mental harm on them. «The use of custodial measures should aim at preventing the repeated crime, which includes explaining to the offender about the negative impact of his/her behaviour and reconciliation with the victim/those affected» $[14, \mathrm{p}$. 80]. As the Convention on the Rights of the Child explains, all actions that concern children must be based on the main objective, such as protecting "the best interests of the child" [16, art. 3]. If it is absolutely necessary to place the child in a prison, the prison authorities should use coercive measures against him/her in exceptional cases only, ensuring full access to education, training, sports activities, rehabilitation services and personal development programs. Based on his/her age, the child shall have the right to maintain contact with his or her family.

International standards primarily focus on the use of early conditional release. They encourage the States to use early conditional release more frequently and efficiently. However, the forms and methods of post-release supervision and support for effective social reintegration should not be overlooked. «uveniles released conditionally from an institution shall be 
assisted and supervised by an appropriate authority and shall receive full support by the community» $[17$, Rule 28.2].

The Havana Rules gives priority to the use of individual approaches to juveniles, with particular emphasis on juveniles with disabilities, and states that «as soon as possible after the moment of admission, each juvenile should be interviewed, and a psychological and social report ... should be prepared» [18, Rule 27]. The purpose of the interview is determining the most appropriate placement for the juvenile within the facility and the specific type and level of care and programme required and to be pursued. The rules set out restrictions that a juvenile should only be placed under conditions that take full account of their particular needs, status and special requirements according to their age, personality, sex, as well as physical and mental health, and which ensure their protection from harmful influences. The Rules also indicate the necessity of considering that «each juvenile is physically able to participate in the available programmes of physical education. Remedial physical education and therapy should be offered, under medical supervision, to juveniles needing it» [18, Rule 47].

The Rules also discuss medical services for juvenile offenders and their availability, which should be appropriate to their age, sex and other requirements of the juveniles concerned, and services staffed by trained personnel. The Rules also include definitions that place a much higher demand in relation to juveniles, for example: «The medical services provided to juveniles should seek to detect and should treat any physical or mental illness, substance abuse or other condition that may hinder the integration of the juvenile into society» [18, Rule 51].

Discipline and control are integral parts of the penitentiary system, but its use is particularly depressing to a detained juvenile, with particular sensitivity. Therefore, any disciplinary measures and procedures should maintain the interest of safety and an ordered community life and should be consistent with the upholding of the inherent dignity of the juvenile and the fundamental objective of institutional care, namely, instilling a sense of justice, self-respect and respect for the basic rights of every person [18, Rule 66].The process of serving a sentence by a juvenile should be subject to systematic control and inspection, as it must comply with the standards of child development in the community, firstly, in order for him/her to be readily integrated into the public life after release and, secondly, to avoid stigmatization.

Personnel working with juveniles and their qualification is utterly important part of the penitentiary system and its role in achieving the purpose of punishment is significant. All international standards aimed at enhancing the effectiveness of the penitentiary system emphasize that it should include a sufficient number of specialists, such as: educators, vocational instructors, social workers, psychologists and psychiatrists. The rules set out the selection procedures, focusing on characteristics of the specialists, such as: humanity, ability and professional capacity to deal with juveniles, etc. The Rules also refer to the specificities of training and explains that «the personnel should receive such training as will enable them to carry out their responsibilities effectively, in particular training in child psychology, child welfare 
and international standards and norms of human rights and the rights of the child» [18, Rule 85].

\section{Life- and Long-Term Prisoners} with Disabilities.

When defining long-term imprisonment, we will inevitably come across terminological differences about what falls under this category. In a number of prison systems, for example in some Scandinavian countries, anyone serving over six months in prison is considered a long-term prisoner. On the other hand, there are prison systems, for example, in Eastern European countries, where a long-term prisoners someone serving more than 10 years of imprisonment. In the United States there are cases where prisoners are sentenced to hundreds of years, which is obviously much more than a normal life expectancy [10, p. 151].

In international standards, which regulate the procedures of serving a sentence by life sentence and other long-term prisoners, the main focus is on identifying individual needs and developing procedures of serving a sentence focused on these needs, meaning that mandatory individual sentence planning should be introduced and implemented, and the comprehensive sentence plans should be prepared for each individual prisoner «as far as possible with the active participation of the prisoner and, particularly towards the end of a detention period, in close co-operation with post-release supervision and other relevant authorities» [19, art. 9].

The normalization principle specifies that prison life should be arranged so as to approximate as closely as possible to the realities of life in the community [19, art. 4]. The significance of this provision is that prisoners of this category should not experience a degree of institutionalization and isolation from the community so that they do not have difficulties of social reintegration and return back to prison for lack of other alternatives. This risk is the highest for prisoners with disabilities who, due to their condition, require systematic care and assistance.

It is logical that when managing life-sentence and long-term prisoners, it is important to consider their dangerous nature, including the seriousness of the crime, the socially harmful behaviour and other circumstances, however, among these circumstances the main focus should be given to disabilities, which reduces the impending danger coming from the person and emphasizes his/her multiple needs. It should also be borne in mind that tougher security measures combined with their isolation from other prisoners and restrictions on their movement may cause their physical and mental health to deteriorate [1, p. 75]. This should be the approach of the policy for serving a sentence by life sentence and long-term prisoners with disabilities, as such prisoners pose less risk, due to their physical condition. Thus, the measures taken within their sentence planning should aim to release them as soon as possible and reintegrate them into society.

\section{Conclusion.}

This article does not attempt to comprehensively review and cover all the prisoners with disabilities with multiple needs and their sentencing standards. At the present stage it mainly deals with the more common forms, on the basis of which it attempts to recommend specific standards of approach to multiple needs to the penitentiary system. 
Initially, in order to create an effective environment of serving a sentence for prisoners with multiple needs, it would be recommended for the penitentiary system to take the following steps:

a. Introduce the term «multiple needs» in legislation and in practice, which will enable the penitentiary system to properly classify the condition of persons with disabilities, as well as each of their needs and, ultimately, to plan the sentence of persons with multiple needs with respect to their honour and human dignity and without inflicting any physical or psychological harm on them;

b. Elaborate protective mechanisms, which are not related to disciplinary measures, because besides the risks, related to multiple needs, that are associated with the living environment, low qualification of personnel, inadequate health care, lack of programs and other factors, there is also a hierarchy of discrimination created by the internal criminal subculture, which makes the already difficult situation of persons with disabilities even more complicated.

c. Introduce the institute of Individual Sentence Planning, which will be available in all penitentiary establishments and to all categories of persons with disabilities depending on their needs.

d. Create the common database accessible to all relevant staff, which allows to start planning appropriate measures for the PWDs with multiple needs upon their admission to the establishment, in order to prevent any risks of human rights violations, discrimination or ill-treatment and to contribute to their adaptation to the environment for serving the sentence.

\section{References}

1. Cuéllar A and others, Vulnerable Groups of Prisoners: A Handbook (Center for the Study of Democracy 2015).

2. Imprisonment Code of Georgia, 09 March 2010.

3. Criminal Executive Code of Ukraine, 11 July 2003.

4. $\quad$ Criminal Executive Code of the Kyrgyz Republic, 24 January 2017;

5. The Code of the Republic of Azerbaijan on the execution of sentences, dated July 14,2000 and legislations of other countries.

6. United Nations Office on Drugs and Crime (UNODC), Atabay T, Handbook on Prisoners with Special Needs (Criminal Justice Handbook Series) (United Nations 2009).

7. UN General Assembly, United Nations Standard Minimum Rules for the Treatment of Prisoners (the Nelson Mandela Rules) 2016, UN Doc A/RES/70/175.

8. National Center for Transgender Equality, LGBT People and the Prison Rape Elimination ACT, 2012.

9. National Prison Rape Elimination Commission, Report, 2009.

10. Coyle A, A Human Rights Approach to Prison Management: Handbook for Prison Staff (International Center for Prison Studies 2009).

11. UN General Assembly, United Nations Rules for the Treatment of Women Prisoners and Non-Custodial Measures for Women Offenders (the Bangkok Rules) 2010, UN Doc A/C.3/65/L.5.

12. United Nations Office on Drugs and Crime (UNODC), Atabay T, Handbook for Prison Managers and Policymakers on Women and Imprisonment (United Nations 2008). 
13. Khasia Z, 'A General Overview of International Standards for Juvenile Sentencing' (2017) 1 General Overview of Current Issues in Criminal Justice.

14. Shalikashvili M, Mikanadze G, Juvenile Justice (Meridiani 2016).

15. European Union Agency for Fundamental Rights (FRA) and Council of Europe (CoE), Handbook on European Law Relating to the Rights of the Child (Publications Office of the European Union 2015)

16. UN General Assembly, Convention on the Rights of the Child, 20 November 1989, United Nations, Treaty Series, vol. 1577.

17. UN General Assembly, United Nations Standard Minimum Rules for the Administration of Juvenile Justice (the Beijing Rules): resolution/adopted by the General Assembly, 29 November 1985, UN Doc A/RES/40/33

18. UN General Assembly, United Nations Rules for the Protection of Juveniles Deprived of Their Liberty (the Havana Rules): resolution/adopted by the General Assembly, 2 April 1991, UN Doc A/RES/45/113.

19. Council of Europe, Recommendation Rec (2003) 23 of the Committee of Ministers to member states on the management by prison administrations of life sentence and other long-term prisoners, 2003.

Хасія 3. М., аспірант Тбіліського державного університету, радник Міжнародного комітету Червоного Хреста з питань в'язничної системи

e-mail: maiakhasia@gmail.com

\section{Особи з обмеженими можливостями та їх потреби в установах виконання покарань}

У статті розглянуто особливості відбування покарання у виді позбавлення волі спеціальними категоріями ув'язнених інвалідів з особливими потребами, з якими періодично стикається будь-яка установа виконання покарань у своїй практиці.

Усім зрозуміло, що засуджені особи з обмеженими можливостями $є$ вразливою категорією. Це обумовлено їх станом, оскільки певні фізичні та психічні вади зумовлюють особливу вразливість таких осіб у досить специфічному закритому місці, яким є установи виконання покарань. Самі по собі, інваліди належать до спеціальної категорії в установах виконання покарань. Більш того, серед них є особи, які належать до інших спеціальних категорій, що обумовлює їх складові потреби. Однак законодавство, що регулює пенітенціарну систему багатьох країн, зокрема пострадянських, не визнає статусу осіб зі складовими потребами.

До такої категорії ув'язнених слід віднести осіб, які мають обмежені можливості та належать до релігійних, етнічних та расових меншин; іноземців; жінок; неповнолітніх; ЛГБТ. Особи, які належать до зазначеної категорії, складають особливо високу групу ризику саме через їх складові потреби. Такі потреби та способи їх задоволення треба всебічно оцінювати, а також планувати відповідну діяльність персоналу установ виконання покарань 3 огляду на поєднання з потребами, пов'язаними з інвалідністю таких осіб. 
Мета статті - обговорити та пояснити важливість надання деяким ув'язненим інвалідам статусу, що відповідає їх потребам, а також необхідність задоволення таких потреб у контексті роботи персоналу установ виконання покарань. Для них слід створити певні умови для відбування покарання нарівні з іншими засудженими, дотримуючись прав людини і громадянина, зберігаючи повагу до їх честі та гідності.

Ключові слова: особа з обмеженими можливостям; належні умови проживання; адаптоване середовище; установа виконання покарань; бар'єри; лікування; визначення статусу; покарання.

Надійшла до редакції 02.08.2019 